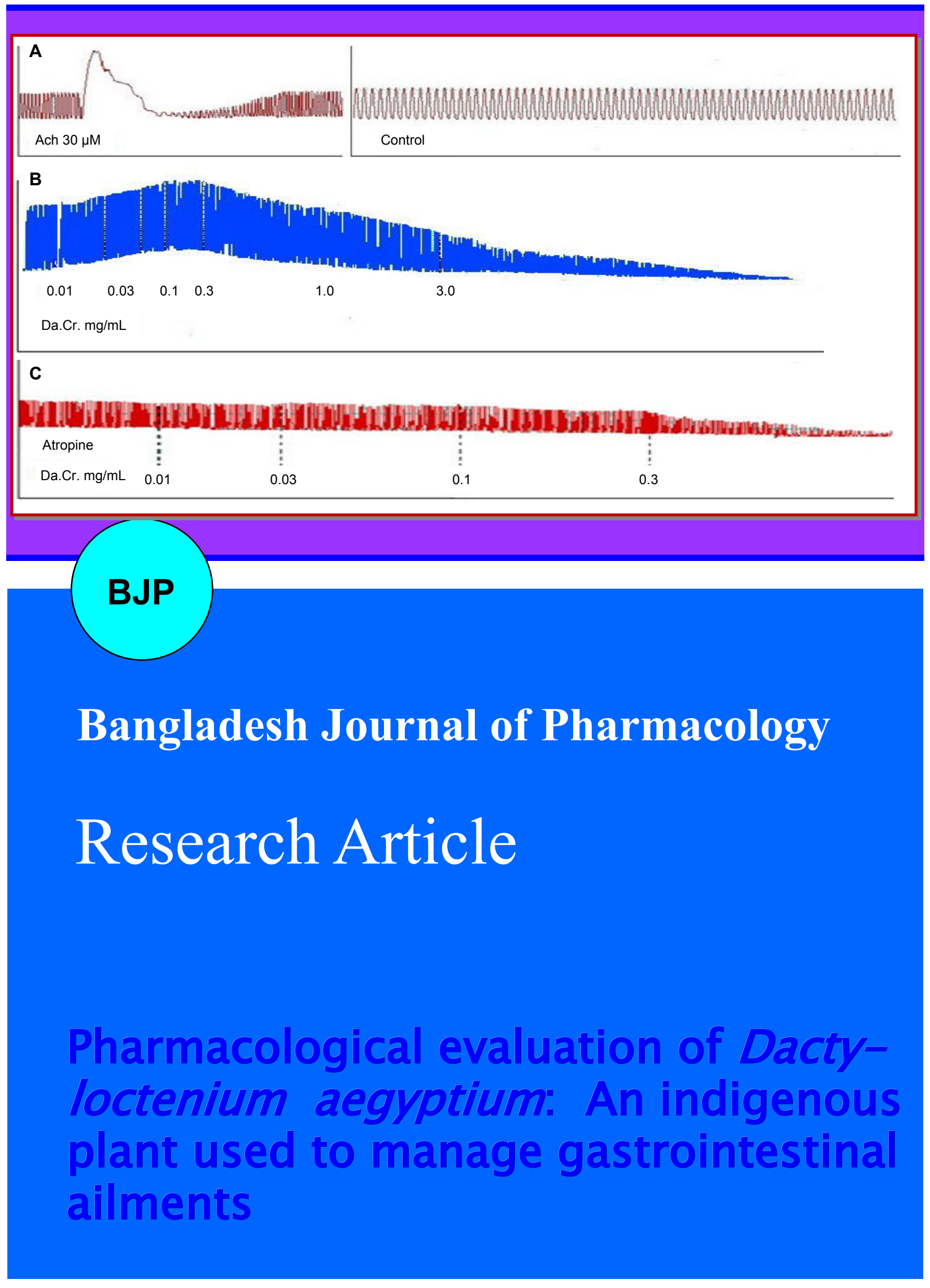




\section{Pharmacological evaluation of Dactyloctenium aegyptium: An indigenous plant used to manage gastrointestinal ailments}

\section{Khalid Hussain Janbaz and Fatima Saqib}

Faculty of Pharmacy, Bahauddin Zakariya University, Multan, Punjab, Pakistan.

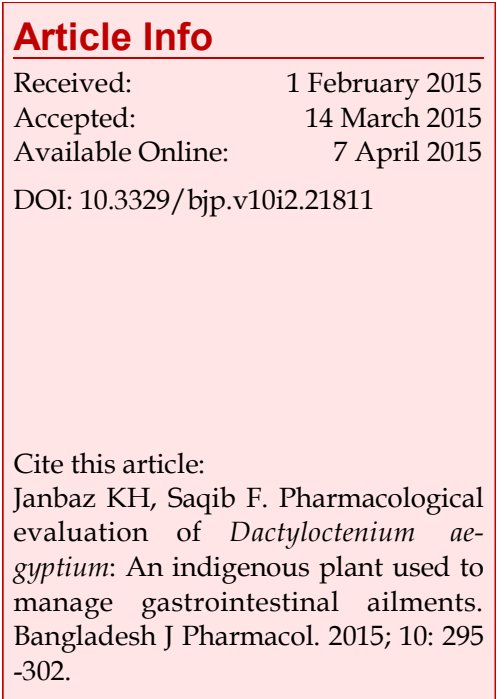

\begin{abstract}
Crude extract of Dactyloctenium aegyptium and its fractions were evaluated to rationalize its folkloric use in gastrointestinal ailments. In spontaneous contracting rabbit jejunum preparation, D. aegyptium exert concentrationdependent spasmogenic effect $(0.01-0.1 \mathrm{mg} / \mathrm{mL})$ followed by spasmolytic effect at higher doses $(0.3-3.0 \mathrm{mg} / \mathrm{mL})$. Pretreatment of the tissue preparations with atropine resulted in suppression of the spasmogenic response. Further-more, D. aegyptium $(1.0 \mathrm{mg} / \mathrm{mL})$ caused relaxation of $\mathrm{K}^{+}(80$ $\mathrm{mM}$ )-induced spastic contractions in isolated rabbit jejunum preparations and there was non-parallel shift in $\mathrm{Ca}^{++}$dose response curves towards right (0.1$0.3 \mathrm{mg} / \mathrm{mL}$ ). These findings were found to be comparable with verapamil, a standard $\mathrm{Ca}^{++}$channel blocker. The solvent-solvents fractionation reflected segregations of spasmogenic and spasmolytic effects in respective aqueous and dichloro-methane fractions. The above-mentioned findings reflected, presence of cholinergic as well as $\mathrm{Ca}^{++}$channel blocking activity in ethanolic extract of $D$. aegyptium thus providing scientific basis for its folkloric use in constipation and diarrhea.
\end{abstract}

\section{Introduction}

Dactyloctenium aegyptium (L.) Beauv (Synonyms: Eleusine aegyptia; Family: Gramineae) is a common coarse grass; known by multiple vernacular names including madhana, bhobra, chimbari, takraa, makaraa, timida (Khare, 2007), beach wire grass, coast button grass, duck grass, durban crowfoot, finger comb grass, four-finger grass (Kirtikar and Basu, 1987), Egyptian finger grass and Egyptian crowfoot grass (Quattrocchi, 2006). It is native to Asia and widely distributed throughout the plains of Pakistan, Afghanistan, Israel, Lebanon, Turkey, India, Nepal, Sri Lanka, Malaysia, Myanmar, Philippines, China, Japan, Singapore, Thailand, Vietnam, New Guinea, Algeria, Morocco, Egypt, Sudan, Tunisia and Libya (Clayton et al., 2006). Its flowering time is from July to August (Baquar, 1989).

Phytochmical investigations resulted in isolation of oxalic acid (Khan, 2002) and oxalates, glutamic and aspartic acids, cystine and tyrosine from aerial parts, while roots contain saponins and carbohydrates (Ghani, 2003). In some areas grass is also reported to contain glycosides (Bor, 1960; Holm et al., 1977; Randall, 2002; Khan, 2002).

D. aegyptium has folkloric repute as astringent, bitter tonic, anti-anthelmintic and used to treat gastrointestinal, biliary and urinary ailments, polyurea (Khare, 2007), fevers (Choudhury et al., 2010), small pox (Sanglakpam et al., 2012), heart burn, immunodeficiency (Kipkore et al., 2014), urinary lithiasis, spasm of maternity and renal infections (Gupta et al., 1966; Kiritikar and Basu, 1987; Robbins., 2002 ), gastric ulcers and wounds healing (Nadkarni, 2002; Khare, 2007; Kirtikar and Basu, 1987). The seeds are used by tribesmen to prepare liquor as well as famine food with unpleasant taste (Sahal et al., 2014; Bor, 1960). The screening for anticancer potential of D. aegyptium 
revealed apoptotic inducing capability of plant extract on human lung and cervical cancer cell lines (Hansakul et al., 2009). The plant extracts has been reported to exert moderate antimicrobial activity against some strains of pathogenic bacteria (i.e., Proteus vulgaris, Escherichia coli, Bacillus cereus, Salmonella typhi, Klebsiella pneumonia, Pseudomonas aeruginosa and Staphylococcus aureus) and yeast (i.e., Candida albicans) (Abdallah and El-Ghazali, 2013).

Although $D$. aegyptium has traditionally been used to manage gastrointestinal ailments i.e constipation and diarrhea but it was not previously pharmacologically evaluated for the possible mode(s) of action. Present study was undertaken to explore the pharmacological potential of the crude ethanolic extract and its solvent fractions to provide mechanistic basis for its folkloric uses in gastrointestinal ailments.

\section{Materials and Methods \\ Collection and extractation of plant material}

Aerial parts of D. aegyptium were collected from the botanical garden of Bahauddin Zakariya University, Multan Pakistan in June 2013 and authenticated with the kind cooperation of Prof. Dr. Altaf Ahmad Dasti, an expert taxonomist from Institute of Pure and Applied Biology, Bahauddin Zakariya University, Multan, Pakistan vide voucher number Fl. P 144-5, deposited in the herbarium of the same institution. The plant material was subjected to shade drying, rendered free of foreign material through manual picking and grinded with the help of herbal grinder to a coarse powder. About $1 \mathrm{~kg}$ of powdered plant material was macerated with $70 \%$ aqueous etha-nol at $25^{\circ} \mathrm{C}$ for 7 days in a wide- mouth amber colored glass container for 7 days with occasional shaking. The soaked material was passed through muslin cloth to remove the vegetative debris and obtained fluid was then filtered through Whatman 1 filter paper. The above-mentioned extraction procedure was repeated thrice and filtrates of these three macerations were mixed. The solvent was subjected to evaporation at $37^{\circ} \mathrm{C}$ under reduced pressure on rotary evaporator (Rotavapor, BUCHI Labortechnik AG, Model 9230, Switzerland) attached with a vacuum pump and a recirculation chiller to obtain a dark green extract (Da.Cr) with approximate yield of $31 \%$.

Solvent-solvent extraction (fractionation) was performed following dissolution of $20 \mathrm{~g}$ of crude ethanol extract of D. aegyptium in about $200 \mathrm{~mL}$ of distilled water to which $200 \mathrm{~mL}$ of dichloromethane (DCM) was added and shaken vigorously in a separating funnel and organic layer was separated. The procedure was repeated thrice and individually collected DCM fractions were pooled. The organic portion was evaporated on rotary evaporator to obtain the dichloromethane fraction (Da.DCM), while the aqueous portion was lyophilized to remove moisture contents (Da.aq) with respective yields 18 and 27\% (Bashir et al., 2006). Ethanol crude extract of $D$. aegyptium and its fractions were stored in amber glass container at $-20^{\circ} \mathrm{C}$.

\section{Chemicals and drugs}

The chemical used in these experiments were of reagent analytical research grade. Potassium chloride, acetylcholine chloride, ethylene diamine tetra-acetic acid (EDTA) and atropine sulfate were purchased from Sigma Chemical Co. St Louis, MO, USA, calcium chloride, glucose, magnesium sulfate, potassium dihydrogen phosphate, sodium bicarbonate, sodium dihydrogen phosphate, and ethanol were obtained from Merck, Dermstadt, Germany. Ammonium hydroxide, sodium chloride and sodium hydroxide were purchased from BDH Laboratory Supplies, Poole, England. Stock solution, subsequent dilutions and physiological salt solutions were made fresh in distilled water on the day of experiment.

\section{Extract solution preparation}

About $3 \mathrm{~g}$ of the crude ethanolic extract of D. aegyptium was dissolved in $10 \mathrm{~mL}$ of distilled water to prepare 0.3 $\mathrm{g} / \mathrm{mL} \mathrm{w} / \mathrm{v}(300 \mathrm{mg} / \mathrm{mL})$ of stock solution. The serial dilutions to $30 \mathrm{mg} / \mathrm{mL}, 3 \mathrm{mg} / \mathrm{mL}$ and $0.3 \mathrm{mg} / \mathrm{mL}$ of $\mathrm{Da} . \mathrm{Cr}$ were made fresh on the day of experiment from the stock solution.

\section{Animals and housing conditions}

The local breed adult (male/female) albino rabbits (1.0$1.5 \mathrm{~kg}$ ) of 6-7 months in age, purchased from local market were maintained in animal house of Faculty of Pharmacy, Bahauddin Zakaryia University, Multan under controlled environmental condition $\left(23-25^{\circ} \mathrm{C}\right)$, and provided with fresh green fodder and tap water ad libitum. The animals were subjected to overnight fasting but provided free access to $\mathrm{H}_{2} \mathrm{O}$ prior to experiments. All the experiments performed were in compliance with the rulings of Institute of Laboratory Animal Resources Commission on Life Sciences (NRC, 1996), and was approved by the Ethical Committee of Bahauddin Zakaryia University, Multan vide letter No. EC /01PhDL/2013 dated $4^{\text {th }}$ September, 2013.

\section{Prelimimnary phytochemical analysis}

The crude ethanolic extract of D. aegyptium was subjected to phytochemical analysis for the detection of alkaloids, saponins, tannins, Phenol, anthraquinones and flavonoids (Evans, 2006). Appearance of yellowish brown color on mixing of dragendorff's reagent with $\mathrm{HCl}$ treated aqueous plant extract solution, confirmed the presence of alkaloids in extract. Formation of froth on vigorous shaking of the aqueous extract solution, confirmed the presence of saponin. Development of 
bluish green color on mixing of aqueous $\mathrm{FeCl}_{3}$ with extract solution indicated presence of phenols and tannins. The appearance of pinkish violet or red colour on exposure to $\mathrm{NH}_{4} \mathrm{OH}$ of the mixture of benzene with aqueous solution of plant extract already acidified with $1 \% \mathrm{HCl}$ confirmed presence of anthraquinones among the plant constituents. The plant material was confirmed positive for flavonoids on appearance of yellow color with $\mathrm{AlCl}_{3}$ reagent.

\section{In vitro experiments on isolated rabbit jejunum preparations}

The rabbits were sacrificed subsequent to a blow on the head, abdomens incised and jejunums dissected out. The mesenteries were removed and cut into segments of about $2 \mathrm{~cm}$ in length. The segments were mounted between two stainless steel hooks in $10 \mathrm{~mL}$ tissue bath containing normal Tyrode solution ( $\mathrm{pH}$ 7.4) maintained at $37^{\circ} \mathrm{C}$ by means of circulating thermo regulator and aerated with carbogen $\left(95 \% \mathrm{O}_{2}+5 \% \mathrm{CO}_{2}\right)$. A preload of $1 \mathrm{~g}$ was applied and the tissue was allowed to be equilibrated for a period of $30 \mathrm{~min}$ during which the tissue was washed with fresh fluid after every $10 \mathrm{~min}$ intervals prior to exposure to any test material. Subsequently, the tissue preparations were repeatedly exposed to acetylcholine $(30 \mu \mathrm{M})$, followed by washing with Tyrode solution to stabilize tissue preparations as well as recording of the sub-maximal response in order to compare magnitude of the observed spasmogenic effect of test material with acetylcholine-induced contractile response. The spontaneous contractions were recorded isotonically through a Power Lab Data Acquisition System (AD Instruments, Australia) (Janbaz et al., 2014). The spontaneous rhythmic contractions in isolated rabbit jejunum preparations, allows testing of relaxant and/or contractile activities (Gilani et al., 2005). The contractile activity of test materials on isolated rabbit jejunum preparations is comparable to that of acetylcholine (ACh), which can be suppressed on pretreatment with atropine $(0.1 \mu \mathrm{M})$ (Janbaz et al., 2013).

\section{Determination of calcium channel blocking activity}

The $\mathrm{Ca}^{++}$channel blocking activity of the test material was determined following application on $\mathrm{K}^{+}(80 \mathrm{mM})$ induced spastic contractions in isolated rabbit jejunum preparations (Farre et al., 1991). The isolated rabbit jejunum preparations following exposure to $\mathrm{K}^{+}(80 \mathrm{mM})$ exhibited a sustained contraction, on which test material was applied by addition to the isolated tissue bath in a cumulative fashion (Van-Rossum, 1963). The $\mathrm{K}^{+}(80$ $\mathrm{mM}$ )-induced contractions in isolated smooth muscle preparations has been reported to be mediated through influx of $\mathrm{Ca}^{++}$from extracellular fluid, and the substances capable to inhibit such types of contractions are speculated to be acting through blockade of the $\mathrm{Ca}^{++}$ channels (Bolton, 1979). The $\mathrm{Ca}^{++}$channel blocking effect of the test material was confirmed further by the previously reported method (Saqib et al., 2012). The isolated rabbit jejunum preparations were allowed to be stabilized in normal Tyrode solution, which was subsequently replaced for $45 \mathrm{~min}$ with a solution containing normal concentration of $\mathrm{K}^{+}$but $\mathrm{Ca}^{++}$was removed and EDTA $(0.1 \mathrm{mM})$ was added to deplete $\mathrm{Ca}^{++}$from the tissues. The isolated tissue preparation was further replaced by a $\mathrm{K}^{+}$-rich and $\mathrm{Ca}^{++}$-free Tyrode's solution having the following composition (mM): $\mathrm{KCl}(50), \mathrm{NaCl}$ (91.04), $\mathrm{MgCl}_{2}$ (1.05), $\mathrm{NaHCO}_{3}$ (11.90), $\mathrm{NaH}_{2} \mathrm{PO}_{4}$ (0.42), glucose (5.55), and EDTA (0.1). After an incubation period of $30 \mathrm{~min}$, the $\mathrm{Ca}^{++}$was added to tissue bath in a cumulative manner to obtain control $\mathrm{Ca}^{++}$dose-response curves (CDRCs). The stepwise increase in contractile activity of the tissue indicated that the extent of contractions was dependant on the availability of extracellular $\mathrm{Ca}^{++}$for $\mathrm{K}^{+}$-induced influx of $\mathrm{Ca}^{++}$. When successive CDRCs for $\mathrm{Ca}^{++}$were found to be superimposable, the tissue was washed and was allowed to be equilibrated with the crude ethanolic extract of $D$. aegyptium for $60 \mathrm{~min}$, and then concentration response curves of $\mathrm{Ca}^{++}$were reconstructed and compared to the CDRCs in absence of extract. The concentration response curves for $\mathrm{Ca}^{++}$were developed in the presence of various concentrations of the extract to assess a possible $\mathrm{Ca}^{++}$channel blocking effect. The $\mathrm{Ca}^{++}$channel blocking activity on the part of plant was confirmed as D. aegyptium caused shifting of the CDRCs constructed in calcium-free medium towards right in a concentration-dependant manner (Bolton, 1979).

\section{Statistical analysis}

The results for spasmolytic and spasmogenic activities are expressed as the mean \pm SEM. The $\mathrm{EC}_{50}$ (median effective concentration) values with $95 \%$ confidence interval were calculated using the computer software GraphPad Prism program version 5.0 for Windows, (Graph-Pad, San Diego, USA). Dose-response curves were analyzed by nonlinear regression sigmoidal response curve (variable slope).

\section{Results}

Preliminary phytochemical investigations on D. aegyptium revealed presence of alkaloids, anthraquinones, flavonoids, saponins and tannins among the ethanol soluble extractable constituents.

The crude ethanol extract of D. aegyptium (Da.Cr) exhibited concentration dependent $(0.01-0.1 \mathrm{mg} / \mathrm{mL})$ contractile effect in isolated rabbit jejunum preparations, but paradoxically it exerted relaxant effect on further increase in tissue bath concentrations (0.3-3.0 $\mathrm{mg} / \mathrm{mL}), \mathrm{EC}_{50}$ value of $0.5071 \mathrm{mg} / \mathrm{mL}$ (95\% CI: 0.2011$0.7539 \mathrm{mg} / \mathrm{mL} ; \mathrm{n}=5$ ) (Figure 1B, 3A). However, pretreatment of the tissue preparations with atropine $(0.1 \mu \mathrm{M})$ resulted in blockade of the contractile response and relaxation of the spontaneous activity was 


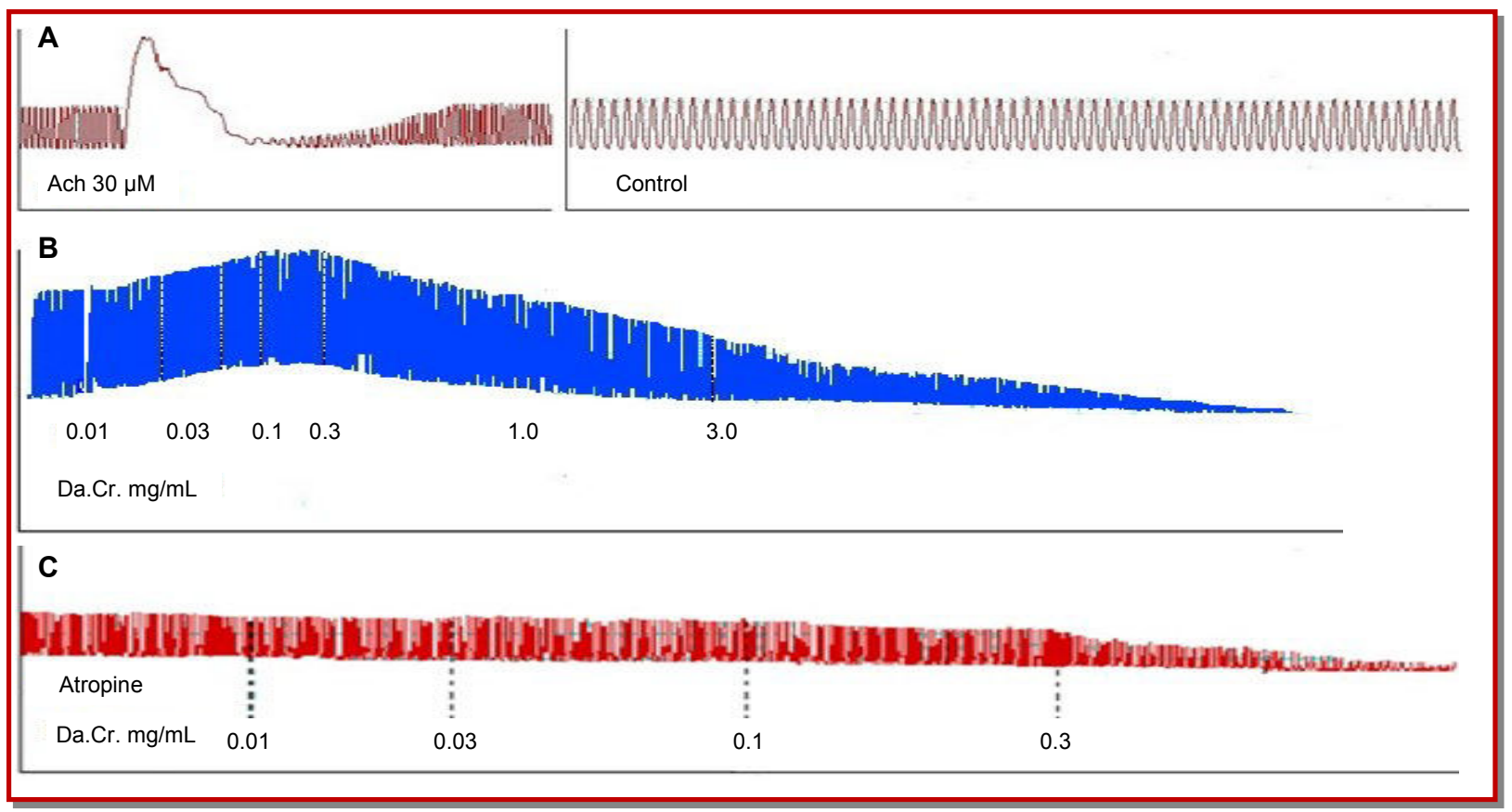

Figure 1: (A) Spontaneous contractions of isolated rabbit jejunum preparations and effect of acetylcholine (30 $\mu \mathrm{M})$ on spontaneous contractions. (B) Effect of D. aegyptium (Da.Cr) on spontaneous contractions of isolated rabbit jejunum preparations. (C) Effect of Da.Cr on spontaneous contractions of isolated rabbit jejunum preparations pretreated with atropine $(0.1 \mu \mathrm{M})$

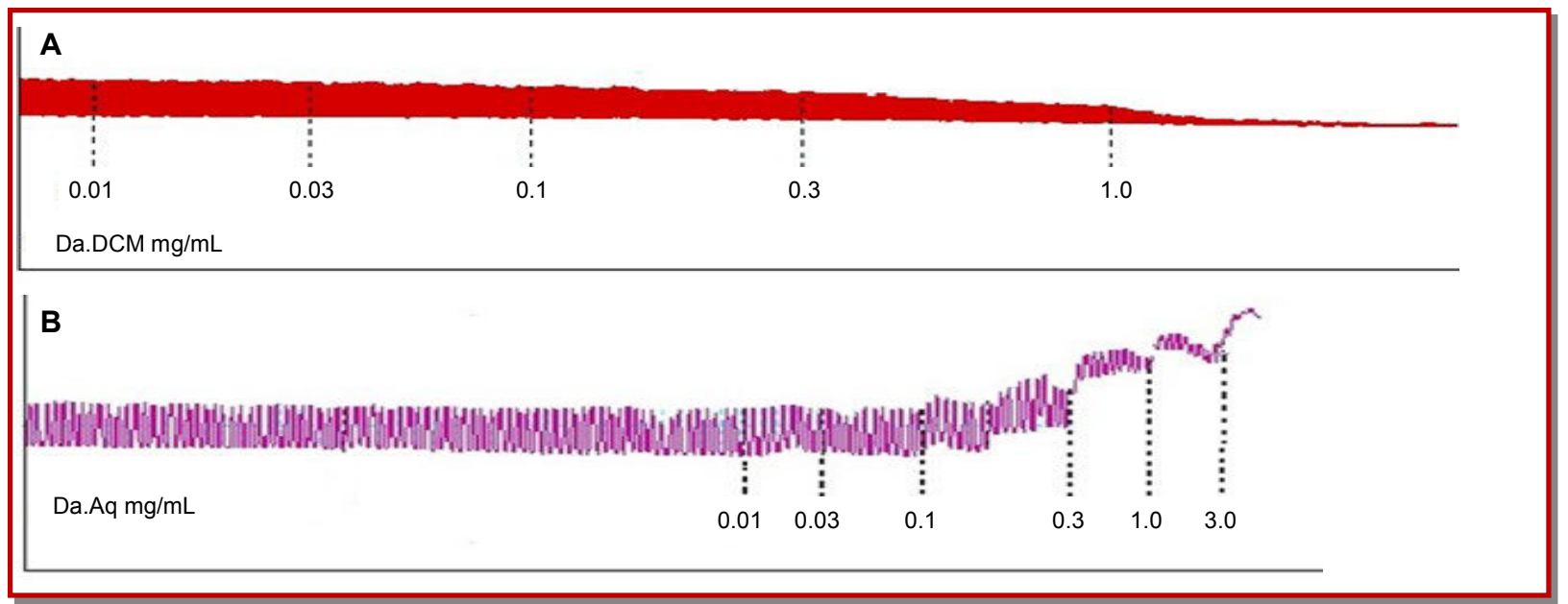

Figure 2: A) Effect of dichloromethane fraction (Da.Dcm) of D. aegyptium on spontaneous contractions of isolated rabbit jejunum preparations. B) Effect of aqueous fraction (Da.Aq) of Da.Cr on spontaneous contractions of isolated rabbit jejunum preparations

observed at tissue bath concentration of $0.01-0.3 \mathrm{mg} /$ $\mathrm{mL}$ with $\mathrm{EC}_{50}$ value of $0.0882 \mathrm{mg} / \mathrm{mL}(95 \% \mathrm{CI}: 0.1011-$ $0.6539 \mathrm{mg} / \mathrm{mL} ; \mathrm{n}=5$ ) (Figure 1C, 3A). Dichloromethane fraction of crude ethanolic extract of $D$. aegyptium inhibited spontaneous contraction at a lower tissue bath concentrations than Da.Cr with $\mathrm{EC}_{50}$ value of $0.1801 \mathrm{mg} / \mathrm{mL}$ (95\% CI: 0.1107-0.6081 mg/mL; $\mathrm{n}=5$ ) (Figure 2A, 3A), whereas aqueous fraction of crude extract of $D$. aegyptium exhibited spasmogenic effect on spontaneous contractions (Figure 2B, 3A).

The Da.Cr caused complete relaxation of $\mathrm{K}^{+}(80 \mathrm{mM})$ induced contractions at tissue bath concentration of 0.01
$-1.0 \mathrm{mg} / \mathrm{mL}$, with $\mathrm{EC}_{50}$ value of $0.1061 \mathrm{mg} / \mathrm{mL}$ (95\% CI: 0.1021-0.6892 $\mathrm{mg} / \mathrm{mL} ; \quad \mathrm{n}=5$ ) (Figure 3B). Dichloromethane fraction of crude ethanolic extract of D. aegyptium inhibited $\mathrm{K}^{+}(80 \mathrm{mM})$-induced contractions at a lower tissue bath concentrations than Da.Cr with $\mathrm{EC}_{50}$ value of $0.0491 \mathrm{mg} / \mathrm{mL}(95 \% \mathrm{CI}$ : 0.0194-0.0650 mg/mL; $\mathrm{n}=5$ ) (Figure 3b), whereas aqueous fraction of crude extract of $D$. aegyptium did not produce relaxation of $\mathrm{K}^{+}(80 \mathrm{mM})$-induced contractions (Figure 3B).

Verapamil (standard drug), exhibited a similar pattern of suppression of the spontaneous and $\mathrm{K}^{+}(80$ 


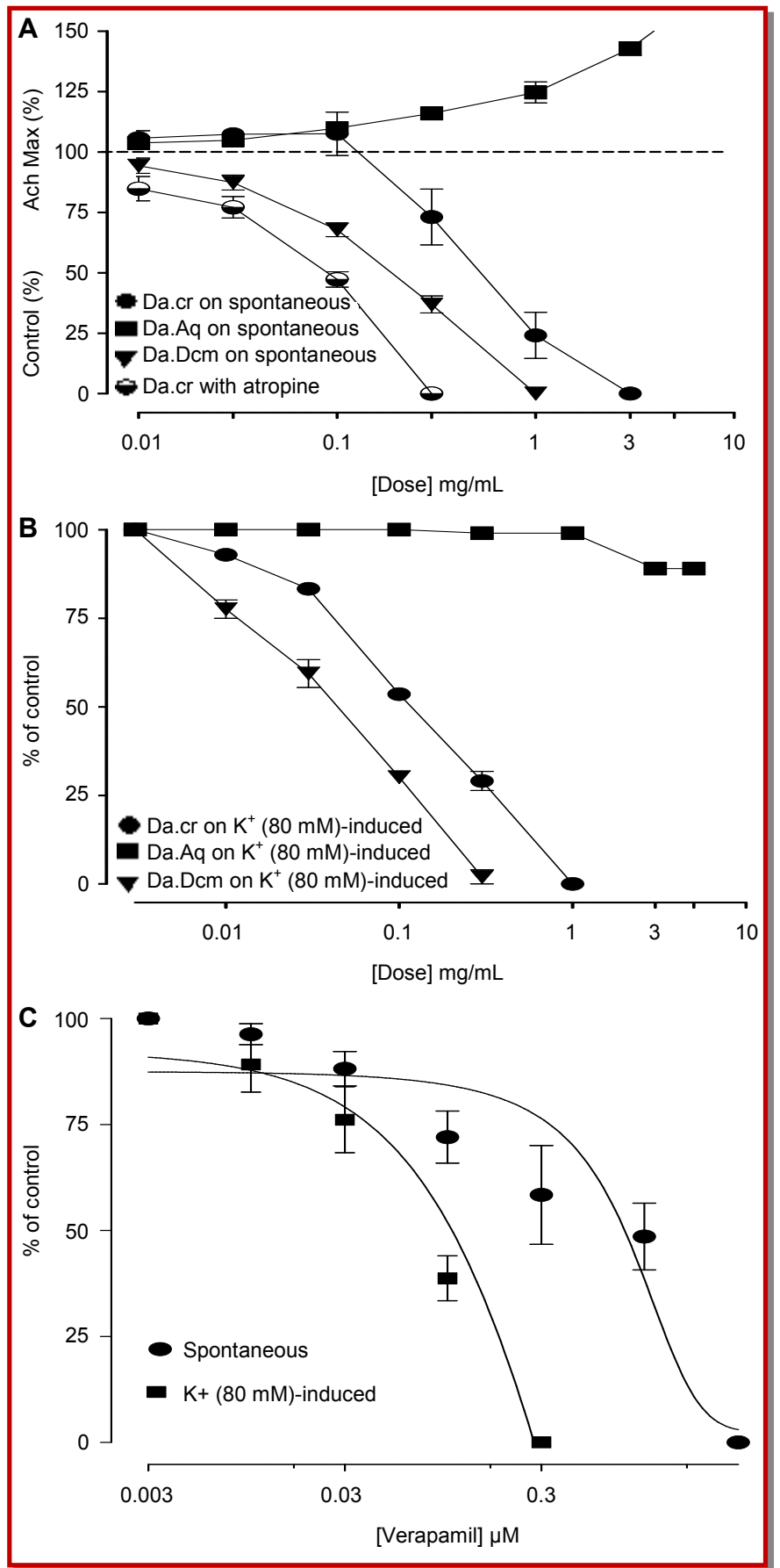

Figure 3: A) Effect of Da.Cr, Da.Dcm and Da.Aq on spontaneous contractions of isolated rabbit jejunum preparations. B) Effect of Da.Cr, Da.Dcm and Da.Aq on $\mathrm{K}^{+}(80 \mathrm{mM})$-induced contractions of isolated rabbit jejunum preparations. C) Effect of verapamil on spontaneous and $\mathrm{K}^{+}(80 \mathrm{mM})$-induced contractions in isolated rabbit jejunum preparations (values shown are mean $\pm \mathrm{SEM}$., $\mathrm{n}=5$ )

$\mathrm{mM}$ )-induced contractions with respective $\mathrm{EC}_{50}$ value of $0.385 \mu \mathrm{M} / \mathrm{mL}(95 \% \mathrm{CI}: 0.2493-0.6394 \mathrm{mg} / \mathrm{mL} ; \mathrm{n}=5)$ and $0.1320 \mu \mathrm{M} / \mathrm{mL}(95 \% \mathrm{CI}: 0.0899-0.1935 \mathrm{mg} / \mathrm{mL}$; $\mathrm{n}=5$ ) (Figure 3C).

The Da.Cr and Da.Dcm on application to the isolated rabbit jejunum preparations at respective tissue bath concentrations of $(0.1-0.3 \mathrm{mg} / \mathrm{mL})$ and (0.01-0.03 $\mathrm{mg} / \mathrm{mL}$ ) caused shifting of the $\mathrm{Ca}^{++}$concentration response curves towards right in a manner omparable to verapamil (0.03-0.1 $\mu \mathrm{M})$ (Figure 4A,B,C).

\section{Discussion}

D. aegyptium has traditionally been used to manage 


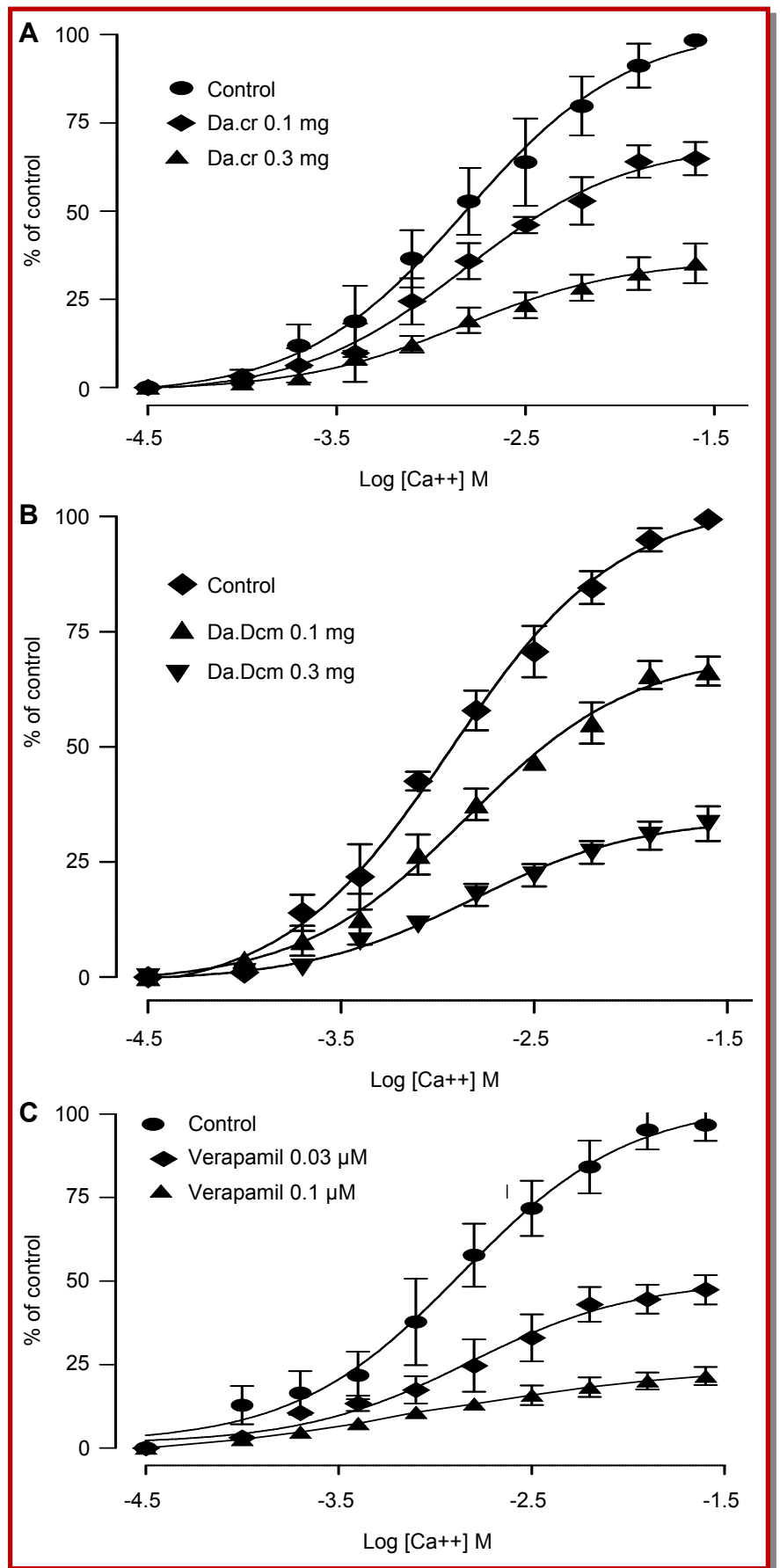

Figure 4: A) Effect of Da. Cr on concentration response curve (CRC) of $\mathrm{Ca}^{++}$in isolated rabbit jejunum preparations. B) Effect of Da. Dcm on CRC of $\mathrm{Ca}^{++}$in isolated rabbit jejunum preparations. C) Effect of verapamil on $\mathrm{CRC}$ of $\mathrm{Ca}^{++}$in isolated rabbit jejunum preparations (values shown are mean \pm SEM., $n=5$ )

gastrointestinal ailments i.e. constipation and diarrhea and present study was undertaken to provide scientific basis for its folkloric uses. The ethanolic extract of $D$. aegyptium (Da.Cr) exerted spasmogenic effect on application to the spontaneously contracting isolated rabbit jejunum preparations at low tissue bath concentrations, while exhibited spasmolytic activity on increasing the bath concentrations, indicating presence of both spas-mogenic and spasmolytic constituents. The spasmogenic response on the part of Da.Cr may possibly due to the presence of some cholinergic muscarinic constituent(s) (Brown and Taylor., 1996), which was confirmed further as pretreatment of isolated rabbit jejunum preparations with atropine (0.1 
$\mu \mathrm{M})$ resulted in supperssion of the spasmogenic activity (Arunlakshana and Schild., 1959) and exhibiting dominant spasmolytic effect. The $D$. aegyptium-induced increase in contractile activity of gastrointestinal tract may provide a scientific basis for it folkloric uses in constipation.

The D. aegyptium induced spasmolytic activity was speculated to be due to the presence of $\mathrm{Ca}^{++}$channel blocking activity (Janbaz et al., 2013a), since increase in free cytoplasmic $\mathrm{Ca}^{++}$concentrations is essential for activation of contractile elements in smooth muscle preparations (Karaki and Weiss, 1983), due either by influx through the L-type voltage-dependant $\mathrm{Ca}^{++}$ channels (VDCs) or release from intracellular $\mathrm{Ca}^{++}$ stores in sarcoplasmic reticulum (Godfraind et al., 1986). The periodic depolarization followed by repolarization is responsible for spontaneous activity in isolated rabbit jejunum preparation. In a state of maximum depolarization, there is rapid influx of $\mathrm{Ca}^{++}$through VDCs and is responsible for the generation of an action potential (Brading, 1981). The observed spasmolytic effect of $\mathrm{Da} . \mathrm{Cr}$ on isolated rabbit jejunum preparation may possibly be mediated either through blockade of VDCs or through inhibition of $\mathrm{Ca}^{++}$released from sarcoplasmic reticulum. The isolated rabbit jejunum preparations on exposure to $\mathrm{K}^{+}(80 \mathrm{mM})$, resulted in opening of VDCs, influx of extracellular $\mathrm{Ca}^{++}$and contraction of smooth muscles (Bolton, 1979; Karaki and Weiss, 1983). The Da.Cr caused relaxation of $\mathrm{K}^{+}(80 \mathrm{mM})$-induced contractions in isolated rabbit jejunum preparations, possibly due to blockade of $\mathrm{Ca}^{++}$channels, which was confirmed further as Da.Cr applied to isolated rabbit jejunum preparations caused not only decrease in tissue response to $\mathrm{Ca}^{++}$, but also rightward shifting in $\mathrm{Ca}^{++}$ concentration response curves, in a manner comparable to verapamil (Janbaz et al., 2014). The $\mathrm{Ca}^{++}$channel blocking activity on the part of $D$. aegyptium can be attributed to the observed presence of alkaloids (Gilani et al., 2005b) and flavonoids (Revuelta et al., 1997; Ghayur et al., 2007) among the plant constituents.

The $\mathrm{Ca}^{++}$channel blockers are known to be effective in hyperactive gut diseases, i.e., diarrhea and abdominal cramps (Brunton., 1996) and presence of such activity in D. aegyptium may provide a scientific basis for its traditional use in hyperactive diseases i.e. diarrhea. The co-existence of laxative and anti-diarrheal activity is reported to be widely distributed among plant kingdom, i.e., Lactuca serriola (Janbaz et al., 2013b), Cletis africana (Khan et al., 2012), Carthamus oxycantha (Gilani et al., 2005a), Calendula officinalis (Bashir et al., 2006) apparently to keep spasmogenic and spasmolytic effects within tolerable limits by the nature.

The liquid-liquid extraction was performed on $D$. aegyptium by using dichloromethane and water. The dichloromethane fraction (Da.DCM) exerted spasmolytic effect on spontaneous as well as $\mathrm{K}^{+}(80 \mathrm{mM})$ - induced contractions, whereas aqueous fraction (Da.Aq) exhibited spasmogenic activity on spontaneous contractions and was without any relaxant effect on $\mathrm{K}^{+}(80 \mathrm{mM})$ -induced contractions, such separation of biological activities on liquid-liquid fractionation has already been reported (Bashir et al., 2006).

This study clearly indicate the presence of two components (cholinomimetic and calcium antagonistic) in crude extract of $D$. aegyptium. The spasmogenic activity may be attributed to some cholinergic constituents which provide mechanistic basis for its use in constipation. The spasmolytic effect may be due to $\mathrm{Ca}^{++}$ channel blocking components that may cause relaxation of gastrointestinal smooth muscles validating its folkloric use in diarrhea.

\section{References}

Abdallah EM, El-Ghazali GE. Screening for antimicrobial activity of some plants from Saudi folk medicine. Glob J Res Med Plant Indig Med. 2013; 2: 189-97.

Arunlakhshana O, Schild HO. Some quantitative uses of drug antagonists. Brit J Pharmacol Chemother. 1959; 14: 48-58.

Baquar SR. Medicinal and poisonous plants of Pakistan. Ist ed. Printas Karachi, Pakistan, 1989, pp 58-59.

Bashir S, Janbaz KH, Qaiser J, Gilani AH. Studies on spasmogenic and spasmolytic activities of Calendula officinalis flowers. Phytother Res. 2006; 20: 906-10.

Bor N. The grasses of Burma, Ceylon, India and Pakistan (excluding Bambuseae). Oxford, Pergamon Press, 1960, p 198.

Bolton TB. Mechanism of action of transmitters and other substances on smooth muscles. Physiol Rev. 1979; 59: 606-718.

Brading F. How do drugs initiate contraction in smooth muscles? Trends Pharmacol Sci. 1981; 2: 261-65.

Brown JH, Taylor P. Muscarinic receptor agonists and antagonists. In: Goodman \& Gillman's: The pharmacological basis of therapeutics. Hardman JG et al (ed). $9^{\text {th }}$ ed. New York, McGraw-Hill, 1996, pp 141-59.

Brunton LL. Agents effecting gastrointestinal water flux and motility, emesis and antiemesis, bile acids and pancreatic enzymes. In: Goodman and Gilman's The pharmacological basis of therapeutics. Hardman JG et al (ed). 9th ed. New York, McGraw-Hill, 1996, pp 917-36.

Choudhury MD, Bawari M, Singha LS. Some antipyretic ethnomedicinal plants of manipuri community of Barak valley, Assam, India. Ethnobot Leaf. 2010; 14: 21- 28.

Clayton WD, Harman KT, Williamson H. Grass base. The Online World Grass Flora, 2006.

Evans WC. Phytochemistry. In: Trease and Evans pharmacognosy. 5th ed. Delhi, Elsevier, 2006, pp 135-50.

Farre AJ, Colombo M, Fort M, Gutierrez B. Differential effects of various $\mathrm{Ca}^{2+}$ antagonists. Gen Pharmacol. 1991; 22: 177181. 
Ghani A. Medicinal plants of Bangladesh with chemical constituents and uses. 2nd ed. Asiatic Society of Bangladesh, Dhaka, Ramna, 2003, p 184.

Gilani AH, Bukhari IA, Khan AR, Khan AU, Farman U, Ahmad VU. Cholinomimetic and calcium channel blocking activities of Carthamus oxycantha. Phytother Res. 2005a; 19: 679-83.

Gilani AH, Ghayur MN, Khalid A, Haq Z, Choudhry MI, Rahman A. Presence of antispasmodic, antidiarrheal, antisecretory, calcium antagonists and acetylcholineestrase inhibitory steroidal alkaloids in Sarcocca saligna. Planta Medica. 2005b; 71: 1-6.

Godfraind T, Miller R, Wibo M. Calcium antagonism and calcium entry blockade. Pharmacol Rev. 1986; 38: 321-416.

Ghayur MN, Khan H, Gilani AH. Antispasmodic, bronchodilator and vasodilator activities of $(+)$-catechin, a naturally occurring flavonoid. Arch Pharma Res. 2007; 30: 970-75.

Gupta RK, Gaur YD, Malhotra SP, Dutta BK. Medicinal plants of the Indian arid zone. J d'agriculture Tropicale. 1966; 13: 247-88.

Hansakul P, Ngamkitidechakul C, Ingkaninan K, Sireeratawong S, Panunto W. Apoptotic induction activity of Dactyloctenium aegyptium (L.) P.B. and Eleusine indica (L.) Gaerth. extracts on human lung and cervical cancer cell lines. J Sci Tech. 2009; 31: 273-79.

Holm LG, Plucknett DL, Pancho JV, Herberger JP. The World's worst weeds: Distribution and biology. East-West Centre, University Press of Hawaii, Hawaii, 1977.

Janbaz KH, Latif MF, Saqib F, Imran I, Haq ZU, Feo VD. Pharmacological effects of Lactuca serriola $\mathrm{L}$. in experimental model of gastrointestinal, respiratory and vascular ailments. Evid-Based Comp Alt Med. 2013a; 2013a: 1- 9.

Janbaz KH, Nisa M, Saqib F, Imran I, Haq MZ, Feo VD. Bronchodilator vasodilator and spasmolytic activities of methanolic extract of Myrtus communis L. J Physiol Pharmacol. 2013b; 64: 479-84.

Janbaz KH, Arif J, Saqib F, Imran I, Ashraf M, Haq MZU, Jaafar HZ, Vincenzo DF. In vitro and in vivo validation of ethnopharmacological uses of methanol extract of Isodon rugosus Wall. ex Benth (Lamiaceae), BMC Comp Alt Med. 2014; 14: 14-71.

Karaki H, Weiss B. Mini-review: Calcium release in smooth muscle. Life Sci.1983; 42: 111-22.

Khan AV. Ethnobotanical studies on plants with medicinal and anti-bacterial properties (PhD Thesis), Aligarh Muslim University, Aligarh, India. 2002, pp. 1-293.
Khan A, Rehman NU, Taweel AMA, Perveen S, Fawzy GA, Gilani AH. Studies on prokinetic, laxative, antidiarrheal and gut modulatory activities of the aqueous-methanol extract of Celtis africana and Underlying Mechanisms. Int J Pharmacol. 2012 ; 8: 701-07.

Khare CP. Indian medicinal plants: An illustrated dictionary. New Delhi, India, Springer, Berlin Heidelberg, 2007, pp 19899.

Kiritikar KR, Basu BD. Indian medicinal plants. Blatter E, Caius JF, Mahaskr KS (eds). Vol III. 2nd ed. Dehradun, India, 1987, pp 1730-32.

Kipkore W, Wanjohi B, Rono H, Kigen GA. Study of the medicinal plants used by the Marakwet Community in Kenya. J Ethnobiol Ethnomed. 2014; 10: 24-28.

Nadkarni KM. Indian materia medica. Vol 2. 3rd ed. Mumbai, Popular Prakashan Pvt. Ltd., 2002, pp 477-88.

National Research Council. Guide for the care and use of laboratory animals. Washington, National Academy Press, 1996, pp 1-7.

Quattrocchi U. CRC World dictionary of grasses: Common names, scientific names, eponyms, synonyms, and etymology. Boca Raton, CRC Press, 2006, pp 1220-21.

Randall RP. A global compendium of weeds. Australia, Shannon Books, 2002.

Revuelta MP, Cantabrana B, Hidalgo A. Depolarization dependent effect of flavonoids in rat uterine smooth muscle contraction elicited by $\mathrm{CaCl}_{2}$. Gen Pharmacol. 1997; 29: 847-57.

Robbins P. The practical politics of knowing: State environmental knowledge and local political economy. J Eco Geo. 2002; 2: 76.

Sahal A, Hoque A, Mallick SK, Panda S. Medicinal uses of grasses by the tribal people in West Bengal: An overview. Int J Basic App Sci. 2014; 3: 63-70.

Sanglakpam P, Mathur RR, Pandey AK. Ethnobotany of Chothe tribes of Bishnupur district (Manipur). Indian J Nat Prod Res. 2012; 3: 414-25.

Saqib F, Janbaz KH, Latif MF, Gilani AH, Bashir S. Ethnopharmacological studies on antispasmodic, bronchodilator and antiplatelet aggregation activities of Blepharis edulis Pers. Asi J Nat App Sci. 2012; 1: 33-45.

Van-Rossum JM. Cumulative concentration-response curves techniques for making concentration response curves in isolated organs and evaluation of drug parameters. Arch Int Pharmacodyn Ther. 1963; 143: 299-330. 


\section{Your feedback about this paper}

1. Number of times you have read this paper 0

2. Quality of paper Click

3. Your comments

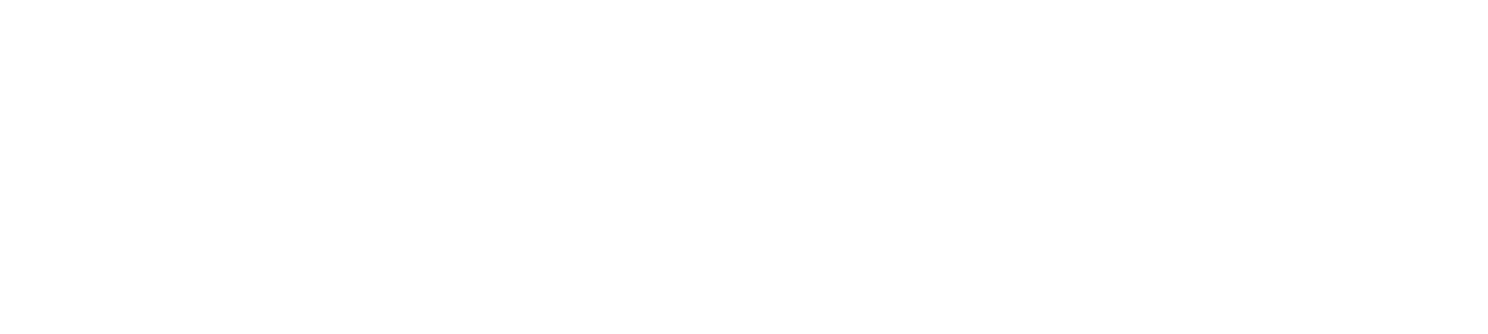

